\title{
Upaya Meningkatkan Hasil Belajar Siswa Melalui Model Pembelajaran Kooperatif Tipe Numbered Heads Together Pada Materi Karakteristik Administrasi Perkantoran SMK Negeri 1 Banda Aceh
}

\author{
Sarinilam \\ SMK Negeri 1 Kota Banda Aceh \\ Email: sarinilamsmk1@gmail.com \\ DOI : 10.32672/jsa.v7i5.1526
}

\begin{abstract}
ABSTRAK
Administrasi perkantoran sebagai salah satu mata pelajaran yang diajarkan dijenjang SMK kelas $\mathrm{X}$ memiliki banyak pokok bahasan yang diatur dalam kurikulum. Di dalamnnya terdapat materi karakteristik administrasi perkantoran. Penelitian ini dilakukan terhadap siswa kelas X SMK Negeri 1 Banda Aceh dengan jumlah siswa 32. Tujuan penelitian ini adalah untuk mendeskripsikan penerapan pembelajaran kooperatif tipe NHT yang dapat meningkatkan hasil belajar siswa kelas X SMK Negeri 1 Banda Aceh pada materi karakteristik administrasi perkantoran. Pendekatan yang digunakan adalah pendekatan deskriptif. Teknik pengumpulan data adalah tes hasil belajar siswa, observasi aktivitas guru, observasi aktivitas siswa dan angket respon siswa. Berdasarkan hasil penelitian diketahui bahwa observasi aktivitas guru mengelola pembelajaran dengan menggunakan model pembelajaran kooperatif tipe NHT pada siklus I adalah baik dengan rata-rata 4,66 dan pada siklus II berada pada kategori sangat baik dengan rata-rata 4,82. Observasi aktivitas siswa diperoleh pada siklus I tidak aktif sedangkan pada siklus II aktivitas siswa aktif. Persentase hasil belajar siswa siklus I adalah 78,86\% siswa tuntas sedangkan pada siklus II adalah 92,50\% siswa tuntas. Sehingga dapat disimpulkan bahwa penerapan model pembelajaran kooperatif tipe NHT dapat meningkatkan hasil belajar siswa pada materi karakteristik administrasi perkantoran di kelas X SMK Negeri 1 Banda Aceh.

Kata Kunci: Hasil Belajar, Model NHT, Administrasi Perkantoran
\end{abstract}

\section{PENDAHULUAN}

Administrasi perkantoran merupakan salah satu bidang keahlian bisnis dan manajemen yang tidak terlepas dari perubahan-perubahan kurikulum guna mencapai hasil pendidikan yang lebih maju. Menurut George Terry (2014:12) pengertian administrasi perkantoran adalah suatu perencanaan, pengendalian dan pengorganisasian pekerjaan pada sebuah perkantoran serta menjadi penggerak kepada mereka yang menjalankannya agar tujuan yang telah ditetapkan dapat tercapai. Hal ini dikarenakan mutu pengajaran administrasi perkantoran mempunyai peranan yang sangat dominan bagi kemajuan bangsa. Administrasi perkantoran sebagai salah satu mata pelajaran yang diajarkan dijenjang SMK memiliki banyak pokok bahasan yang diatur dalam kurikulum.

Berdasarkan pengalaman penulis sebagai guru administrasi perkantoran di SMK Negeri 1 Banda Aceh, siswa belum mampu menunjukkkan prestasi yang 
Sarinilam

menggembirakan. Ini dilihat berdasarkan hasil ujian semester pada tahun-tahun sebelumnya, siswa belum menguasai materi karakteristik administrasi perkantoran. Sebelumnya penulis hanya menerapkan pembelajaran konvensional, dimana guru lebih dominan dalam proses pembelajaran. Setelah mempelajari model-model pembelajaran yang melibatkan siswa secara aktif penulis berkeinginan untuk melakukan inovasi dalam pembelajaran, yaitu dengan menerapkan model pembelajaran kooperatif. Joyce (dalam Johar, 2006:8) menyatakan bahwa: "Model pembelajaran kooperatif merupakan suatu perencanaan atau suatu pola yang digunakan sebagai pedoman dalam merencang pembelajaran di kelas atau pembelajaran dalam tutorial dan untuk menentukan perangkatperangkat pembelajaran termasuk didalamnya buku-buku, film, komputer, dan lain-lain". Model merupakan suatu konsepsi untuk mengajar suatu materi guna mencapai tujuan tertentu.

Menurut Tin Urge (1997:1) bahwa: Pembelajaran kooperatif merupakan strategi belajar diman siswa belajar dalam kelompok kecil yang memiliki tingkat kemampuan yang berbeda-beda. Dalam menyelesaikan tugas kelompok, setiap anggota kelompok saling bekerja sama membantu untuk memahami suatu bahan pembelajaran. Belajar belum dianggap selesai jika salah satu teman kelompok belum menguasai bahan pembelajaran. Rustaman (2003:26) mengatakan "Pembelajaran kooperatif merupakan salah satu pembelajaran yang dikembangkan dari teori kontruktivisme karena mengembangkan struktur kognitif untuk membangun pengetahuan sendiri melalui berpikir rasional". Salah satu tipe pembelajaran kooperatif yaitu tipe Number Heads Together (NHT). Model pembelajaran Number Head Together adalah salah satu model pembelajaran kooperatif yang dirancang untuk Memberikan kesempatan kepada siswa untuk saling sharing ide-ide dan mempertimbangkan jawaban yang paling tepat, meningkatkan semangat kerjasama siswa (Huda, 2013:38). Dalam pembelajaran administrasi perkantoran sekolah menengah kejuruan dapat diterapkan model pembelajaran kooperatif tipe NHT untuk meningkatkan hasil belajar siswa. Karena model ini dapat membangun aktivitas siswa untuk menggali sendiri tentang masalah yang perlu diselesaikan, sedangkan guru bertindak sebagai fasilitator.

Model pembelajaran kooperatif tipe Numbered Heads Together (NHT) pada dasarnya merupakan sebuah variasi diskusi kelompok dengan ciri khasnya adalah guru hanya menunjuk seorang siswa yang mewakili kelompoknya tanpa memberitahu terlebih dahulu siapa yang akan mewakili kelompoknya tersebut. Sehingga cara ini menjamin keterlibatan semua siswa. Cara ini upaya yang sangat baik untuk meningkatkan tanggung jawab individual dalam diskusi kelompok (Nur, 2005:78). Ada beberapa manfaat pada model pembelajaran kooperatif tipe NHT terhadap siswa yang hasil belajar masih rendah yang dikemukan oleh Linda Lundgren (dalam Ibrahim, 2006: 18), antara lain adalah: (a) rasa harga diri menjadi lebih tinggi; (b) memperbaiki kehadiran; (c) penerimaan terhadap individu menjadi lebih besar; (d) perilaku mengganggu menjadi lebih kecil; (e) konflik antara pribadi berkurang; (f) pemahaman yang lebih mendalam; (g) meningkatkan kebaikan budi, kepekaan dan toleransi; dan h) hasil belajar lebih tinggi.

Pemilihan model pembelajaran kooperatif tipe NHT dengan harapan siswa benarbenar terlibat dalam pembelajaran. Keterlibatannya dalam pembelajaran akan memberi makna yang berarti baginya serta akan lebih lama bertahan dalam ingatannya, akhirnya 
hasil belajar yang diperoleh pun akan maksimal. Nawawi (dalam Susanto, 2013: 5) yang menyatakan bahwa hasil belajar dapat diartikan sebagai tingkat keberhasilan siswa dalam mempelajari materi pelajaran di sekolah yang dinyatakan dalam skor yang diperoleh dari hasil tes mengenal sejumlah materi pelajaran tertentu.

\section{METODE PENELITIAN}

Pendekatan yang digunakan dalam penelitian ini adalah pendekatan deskriptif. Adapun jenis penelitian ini adalah Penelitian Tindakan. Menurut Kesumah (2009:9), penelitian tindakan lebih bertujuan memperbaiki kinerja, sifatnya kontektual dan hasilnya tidak untuk digeneralisasi. Namun demikian hasil penelitian tindakan dapat saja diterapkan oleh orang lain yang mempunyai latar belakang yang mirip dengan peneliti. Dengan demikian hasil penelitian ini dapat juga digunakan oleh guru SMK Negeri 1 Banda Aceh lainnya dalam rangka memperbaiki kinerjanya. Subjek penelitian ini adalah siswa kelas $X$ SMK Negeri 1 Banda Aceh dengan jumlah siswa 32 orang. Teknik pengumpulan data yang digunakan dalam penelitian ini adalah melalui tes hasil belajar siswa, observasi kemampuan guru mengelola pembelajaran dan aktivitas siswa, angket respon siswa. Adapun tahap-tahapnya adalah merencanakan, melakukan tindakan, observasi dan refleksi yang terdiri dari dua siklus.

\section{HASIL PENELITIAN DAN PEMBAHASAN Prasiklus}

Sebelum diadakan tindakan kelas, penulis (peneliti) mengajar secara konvensional. Guru cenderung mentransferkan ilmu pada siswa dengan menjadikan siswa objek dalam pembelajaran. Sehingga kemampuan siswa rendah dalam menguasai materi.

Dari hasil tes prasiklus dapat diketahui bahwa siswa yang tuntas sebanyak 16 siswa, sedangkan yang tidak tuntas 16 siswa. Bila dipersenkan, maka persentase jumlah siswa yang telah tuntas adalah 50\%. Siswa yang tidak tuntas persentasenya juga $50 \%$. Adapun rata-rata keseluruhan pada pra siklus adalah 72,19. Hasil pengamatan yang diperoleh peneliti dan dibantu oleh teman sejawat yang akan dijadikan refleksi pada pertemuan pra siklus ini adalah siswa belum aktif dalam mengikuti pembelajaran. Sedangkan hasil pengamatan terhadap peneliti yaitu peneliti kurang menguasai dan mengontrol keaktifan siswa waktu proses belajar mengajar.

\section{Siklus I}

a. Tahap Perencanaan Siklus I

Pada tahap perencanaan, peneliti mempelajari kurikulum sekolah kelas $\mathrm{X}$, membuat silabus, merancang Rencana Pelaksanaan pembelajaran, Lembar Kegiatan Siswa, dan membuat tes siklus I serta kisi-kisinya. Rencana Pelaksanaan pembelajaran berisi skenario pembelajaran yang harus dilaksanakan dalam pembelajaran, agar tujuan pembelajaran yang telah ditetapkan dapat dicapai. Pada tahap ini, peneliti mengacu pada penggunaan model NHT. 
Sarinilam

\section{b. Tahap Pelaksanaan Siklus I}

Pembelajaran pada siklus I ini dilaksanaakan pada 24 - 28 Oktober 2016 dengan alokasi waktu untuk kegiatan belajar mengajar (KBM) adalah (2 x 45 menit) dengan memahami pengertian karakteristik dan karakteristik administrasi, dan menjelaskan karakteristik administrasi perkantoran yang bersifat pelayanan, terbuka dan luas. Pada pertemuan pertama dan kedua peneliti melaksanakan kegiatan pembelajaran sesuai dengan yang direncanakan dalam RPP, sedangkan pada pertemuan ketiga peneliti melaksanakan tes siklus I, guna melihat hasil belajar siswa dengan menggunakan model pembelajaran kooperatif tipe NHT. Hasil tes siklus I siswa dapat dilihat pada tabel di bawah ini.

Tabel 1. Hasil Tes Siklus I

\begin{tabular}{|c|l|c|c|c|}
\hline No & \multicolumn{1}{|c|}{ Nama } & KKM & Nilai & Keterangan \\
\hline 1 & Ainnur Ramadhayanti & 75 & 80 & Tuntas \\
\hline 2 & Ajeng Wulan Dara & 75 & 88 & Tuntas \\
\hline 3 & Alvia Rahmati & 75 & 78 & Tuntas \\
\hline 4 & Chaula Salsabila & 75 & 86 & Tuntas \\
\hline 5 & Cut Anggun Triami & 75 & 65 & Tidak Tuntas \\
\hline 6 & Cut Keumala Nurul Fakhriyyah & 75 & 85 & Tuntas \\
\hline 7 & Cutti Hajar & 75 & 60 & Tidak Tuntas \\
\hline 8 & Dara Rizkina & 75 & 80 & Tuntas \\
\hline 9 & Della Fadhillah & 75 & 80 & Tuntas \\
\hline 10 & Desi Indrayana & 75 & 70 & Tidak Tuntas \\
\hline 11 & Daivina Salim & 75 & 90 & Tuntas \\
\hline 12 & Dian Prayatna & 75 & 78 & Tuntas \\
\hline 13 & Fia Herlika & 75 & 82 & Tuntas \\
\hline 14 & Husna Zaiti & 75 & 85 & Tuntas \\
\hline 15 & M. Iqbar Farisi & 75 & 70 & Tidak Tuntas \\
\hline 16 & M. Dodi Rahmatllah & 75 & 90 & Tuntas \\
\hline 17 & Marlisa Ulfa & 75 & 80 & Tuntas \\
\hline 18 & Miftahul Jannah & 75 & 85 & Tuntas \\
\hline 19 & Mirza Rizkia & 75 & 86 & Tuntas \\
\hline 20 & Mirza Ervirita & 75 & 68 & Tidak Tuntas \\
\hline 21 & Nianda Faradiba Sarbini & 75 & 85 & Tuntas \\
\hline 22 & Nova Sahara & 75 & 80 & Tuntas \\
\hline 23 & Putri Indah Seruni & 75 & 85 & Tuntas \\
\hline 24 & Putri Maryam Gunawan & 75 & 82 & Tuntas \\
\hline 25 & Raihan Aprilia & 75 & 70 & Tidak Tuntas \\
\hline 26 & Renita Shella Ramadhalena & 75 & 79 & Tuntas \\
\hline 27 & Sahlatul Fayza Nabila & 75 & 90 & Tuntas \\
\hline 28 & Sarah Samana & 75 & 80 & Tuntas \\
\hline 29 & Siska Maria & 75 & 85 & Tuntas \\
\hline 30 & Siti Hartini & 75 & 68 & Tidak Tuntas \\
\hline 31 & Syauqi Anshar & 75 & 80 & Tuntas \\
\hline 32 & Wulan Haliza & 75 & 65 & Tidak Tuntas \\
\hline Rata-rata Keseluruhan & & 79,22 \\
\hline Persentase Tuntas & & $21,14 \%$ \\
\hline Persentase Tidak Tuntas & & & \\
\hline & & & $78,86 \%$ \\
\hline
\end{tabular}


Serambi Akademica

Jurnal Pendidikan, Sains, dan Humaniora
Vol. 7, No. 4,

Oktober 2019
pISSN 2337-8085

eISSN 2657- 0998

Berdasarkan tabel di atas dapat diperhatikan bahwa dari 32 siswa yang mengikuti tes siklus I, siswa yang tuntas berjumlah 24 siswa sedangkan tidak tuntas berjumlah 8 siswa. Persentase siswa yang tuntas yaitu sebesar 78,86\% dan yang tidak tuntas sebesar $21,14 \%$. Berdasarkan KKM yang terdapat di SMK Negeri 1 Banda Aceh, siswa tuntas secara individual jika memperoleh nilai minimal 75 dan siswa dikatakan tuntas secara klasikal apabila $\geq 85 \%$ siswa tuntas secara individual. Berdasarkan kriteria tersebut dapat disimpulkan bahwa hasil belajar siswa pada siklus I belum mencapai ketuntasan secara klasikal.

\section{c. Tahap Observasi Siklus I}

Pada tahap ini, guru yang manjadi observasi melaksanakan pengamatan secara langsung terhadap aktivitas guru dan aktivitas siswa selama pembelajaran berlangsung. Hasil pengamatan mereka diisikan pada lembar observasi yang telah peneliti siapkan. Berikut hasil observasi aktivitas guru pada siklus I.

Tabel 3. Observasi Aktivitas Guru Siklus I

\begin{tabular}{|c|c|c|c|c|}
\hline \multirow{2}{*}{ No } & Aspek yang Diamati & \multirow{2}{*}{ RPP I } & \multirow{2}{*}{ RPP II } & \multirow{2}{*}{$\begin{array}{c}\text { Rata- } \\
\text { rata }\end{array}$} \\
\hline & Kegiatan Pendahuluan & & & \\
\hline 1 & $\begin{array}{l}\text { Kemampuan mengaitkan materi yang dipelajari dengan materi } \\
\text { sebelumnya }\end{array}$ & 4 & 5 & 4,5 \\
\hline 2 & $\begin{array}{l}\text { Guru memberikan contoh materi yang dipelajari dengan kehidupan } \\
\text { sehari-hari siswa }\end{array}$ & 4 & 5 & 4,5 \\
\hline 3 & Guru menyampaikan tujuan pembelajaran. & 5 & 5 & 5 \\
\hline 4 & $\begin{array}{l}\text { Guru menjelaskan kepada siswa tentang metode pembelajaran yang } \\
\text { akan digunakan }\end{array}$ & 4 & 5 & 4,5 \\
\hline \multicolumn{5}{|c|}{ Kegiatan Inti } \\
\hline 5 & $\begin{array}{l}\text { Kemampuan membentuk kelompok belajar siswa Guru memberikan } \\
\text { nomor kepada siswa }\end{array}$ & 4 & 5 & 4,5 \\
\hline 6 & $\begin{array}{l}\text { Kemampuan mendorong para siswa agar bekerja sama dalam } \\
\text { menyelesaikan LKS yang diberikan }\end{array}$ & 5 & 5 & 5 \\
\hline 7 & $\begin{array}{l}\text { Kemampuan membimbing siswa untuk berdiskusi dan menemukan } \\
\text { jawaban dari hasil diskusi tersebut serta cara memecahkan soal, } \\
\text { dengan memberikan bantuan terbatas }\end{array}$ & 4 & 5 & 4,5 \\
\hline 8 & Kemampuan mengoptimalkan interaksi siswa dalam belajar & 4 & 5 & 4,5 \\
\hline 9 & Kemampuan memimpin diskusi kelas/menguasai kelas & 5 & 5 & 5 \\
\hline 10 & $\begin{array}{l}\text { Kemampan mendorong siswa untuk menanggapi hasil presentasi } \\
\text { temannya yang bernomor sama }\end{array}$ & 4 & 5 & 4,5 \\
\hline 11 & Kemampuan mendorong siswa untuk mau bertanya & 4 & 5 & 4,5 \\
\hline 12 & Kemampuan mendorong siswa untuk mau mengeluarkan pendapat & 5 & 5 & 5 \\
\hline 13 & Kemampuan memotivasi siswa untuk menjawab pertanyaan & 4 & 5 & 4,5 \\
\hline 14 & $\begin{array}{l}\text { Menghargai berbagai pendapat siswa dan memberikan penghargaan } \\
\text { terhadap hasil belajar siswa sebagai motivasi belajar }\end{array}$ & 3 & 4 & 3,5 \\
\hline \multicolumn{5}{|c|}{ Penutup } \\
\hline 15 & $\begin{array}{l}\text { Kemampuan mengarahkan siswa untuk menemukan sendiri dan } \\
\text { menarik kesimpulan tentang karakteristik administrasi perkantoran }\end{array}$ & 3 & 4 & 3,5 \\
\hline 16 & $\begin{array}{l}\text { Kemapuan menegaskan hal-hal penting intisari berkaitan dengan } \\
\text { pembelajaran }\end{array}$ & 4 & 5 & 4,5 \\
\hline 17 & Kemampuan menyampaikan judul sub materi berikutnya & 4 & 5 & 4,5 \\
\hline
\end{tabular}


Sarinilam

\begin{tabular}{|c|l|c|c|c|}
\hline \multicolumn{1}{|c|}{ memberikan PR serta menutup pelajaran } & & & \\
\hline \multicolumn{2}{|c|}{ Lain-lain } & & & \\
\hline 18 & Antusias guru & 4 & 5 & 4,5 \\
\hline 19 & Antusias siswa & 4 & 5 & 3,5 \\
\hline \multicolumn{2}{|c|}{} \\
\hline
\end{tabular}

Berdasarkan tabel di atas dapat diperhatikan bahwa secara keseluruhan rata-rata aktivitas guru dalam mengelola pembelajaran pada siklus I adalah 4,47. Sesuai dengan taraf keberhasilan tindakan tingkat kemampuan guru maka dapat disimpulkan bahwa pembelajaran pada siklus I berada pada taraf baik. Berdasarkan hasil pengamatan terhadap aktivitas siswa selama pembelajaran berlangsung pada siklus I diperoleh hasil seperti tabel di bawah ini.

Tabel 4. Observasi Aktivitas Siswa Siklus I

\begin{tabular}{|l|c|c|c|c|c|}
\hline \multicolumn{1}{|c|}{ Aspek Pengamatan Aktivitas Siswa } & RPP I & RPP II & $\begin{array}{c}\text { Rata-rata } \\
\text { Aktivitas } \\
\text { Siswa } \\
(\%)\end{array}$ & $\begin{array}{c}\text { Persentase Kesesuaian (P) } \\
\text { Ideal }\end{array}$ & \multicolumn{1}{|c|}{ Toleransi } \\
\hline $\begin{array}{l}\text { Mendengarkan/memperhatikan penjelasan } \\
\text { guru/teman }\end{array}$ & 15,62 & 14,58 & 15,1 & $13 \%$ & $7 \% \leq \mathrm{P} \leq 18 \%$ \\
\hline Membaca/memahami masalah di LKS & 12,5 & 11,45 & 11,98 & $10 \%$ & $5 \% \leq \mathrm{P} \leq 15 \%$ \\
\hline $\begin{array}{l}\text { Menyelesaikan masalah atau menemukan } \\
\text { solusi pemecahan masalah }\end{array}$ & 22,91 & 23,95 & 23,43 & $27 \%$ & $22 \% \leq \mathrm{P} \leq 32 \%$ \\
\hline $\begin{array}{l}\text { Membandingkan hasil temuan diskusi } \\
\text { kelompok dengan hasil diskusi kelompok } \\
\text { lainnya }\end{array}$ & 20,83 & 25,00 & 22,92 & $30 \%$ & $25 \% \leq \mathrm{P} \leq 35 \%$ \\
\hline $\begin{array}{l}\text { Bertanya/menyampaikan pendapat/ide kepada } \\
\text { guru atau teman sekelompok }\end{array}$ & 14,58 & 11.45 & 13,02 & $10 \%$ & $5 \% \leq \mathrm{P} \leq 15 \%$ \\
\hline $\begin{array}{l}\text { Menarik kesimpulan suatu konsep yang } \\
\text { ditemukan atau suatu prosedur yang dikerjakan }\end{array}$ & 10,41 & 10,41 & 10,41 & $10 \%$ & $5 \% \leq \mathrm{P} \leq 15 \%$ \\
\hline $\begin{array}{l}\text { Perilaku yang tidak relevan dengan KBM } \\
\text { (seperti: melamun, berjalan-jalan di luar } \\
\text { kelompok belajarny, membaca buku lain/ } \\
\text { mengerjakan tugas mata pelajaran lain, } \\
\text { bermain-main dengan teman atau mengganggu } \\
\text { teman dan lain-lain) }\end{array}$ & 3,132 & 3,12 & 3,12 & $0 \%$ & $0 \% \leq \mathrm{P} \leq 5 \%$ \\
\hline
\end{tabular}

Berdasarkan tabel di atas dapat diperhatikan bahwa aspek aktivitas siswa pada siklus I yang sudah aktif adalah (1) aspek mendengar/memperhatikan penjelasan guru/teman, (2) membaca/memahami masalah di LKS, (3) menyelesaikan masalah atau menemukan solusi pemecahan masalah, (4) bertanya/menyampaikan pendapat/ide kepada guru atau teman sekelompok, (5) menarik kesimpulan suatu konsep yang ditemukan atau suatu prosedur yang dikerjakan dan (6) perilaku yang tidak relevan dengan KBM masing-masing rataratanya sebesar 15,1, 11,98, 23,43,13,02, 10,41dan 3,12. Rata-rata tersebut berada pada toleransi yang diberikan. Sedangkan aspek aktivitas siswa yang tidak aktif adalah aspek membandingkan hasil temuan diskusi kelompok dengan hasil diskusi kelompoknya dan memiliki rata-ratanya sebesar 22,92 dan berada di luar toleransi 
Serambi Akademica

Jurnal Pendidikan, Sains, dan Humaniora
Vol. 7, No. 4,

Oktober 2019
pISSN 2337-8085

eISSN 2657- 0998

waktu yang diberikan. Berdasarkan kriteria aktivitas siswa, bahwa aktivitas siswa dikatakan aktif jika setiap aspek aktivitas siswa yang diamati aktif. Sehingga dapat disimpulkan bahwa aktivitas siswa pada siklus I tidak aktif.

\section{d. Tahap Refleksi Siklus I}

Berdasarkan hasil observasi pada tindakkan pembelajaran siklus I, diketahui masih banyak kekurangan yang dilakukan guru, diantaranya:1. Siswa kurang termotivasi. 2. Kemampuan prasyarat siswa masih kurang, sehingga ada beberapa siswa yang belum siap dan belum paham. 3. Ada kegiatan siswa selain diskusi pembelajaran yang tidak terperhatikan dan ada kelompok yang kurang memahami cara mengerjakan LKS. Hasil refleksi pada siklus I merupakan catatan untuk peneliti agar pada pertemuan berikutnya tidak mengulangi kekurangan pada pertemuan sebelumnya, yang selanjutnya dilakukan tindakan perbaikan pada pembelajaran sebagai berikut: 1 . Peneliti berusaha memperbaiki baik dalam menggali kemampuan prasyarat siswa, maupun pembahasan materi dan langkah-langkah pembelajaran secara sistematis dan intensif sehingga diharapkan semua siswa memahami langkah-langkah yang harus dilakukan dalam pembelajaran. 2. Pada diskusi kelompok, peneliti harus memberikan bimbingan kepada siswa terutama siswa yang membutuhkan bimbingan. 3. Selanjutnya siswa yang tidak paham dan miskonsepsi pada siklus I, peneliti telah memberikan bimbingan secara bergilir baik dalam tugas kelompok, maupun dalam tugas perorangan, agar benar-benar memahami secara mendasar konsep materi yang diberikan.

\section{Siklus II}

a. Tahap Perencanaan Siklus II

Pada tahap perencanaan, peneliti mempelajari kurikulum sekolah kelas X, membuat silabus, merancang Rencana Pelaksanaan pembelajaran (RPP), Lembar Kegiatan Siswa (LKS), dan membuat soal tes siklus 2. Rencana Pelaksanaan pembelajaran berisi skenario pembelajaran yang merupakan perbaikan siklus pertama dan harus dilaksanaan dalam pembelajaran, agar tujuan pembelajaran yang telah ditetapkan dapat dicapai. Pada tahap ini, peneliti mengacu pada penggunaan model NHT.

\section{b. Tahap Pelaksanaan Siklus II}

Pelaksanaan pembelajaran siklus II merupakan tindakan perbaikan dari pelaksanaan pembelajaran siklus I dalam penelitian ini. Pembelajaran pada siklus II ini dilaksanaakan pada 3 - 7 November 2014 dengan alokasi waktu untuk kegiatan belajar mengajar (KBM) adalah ( 2 x 45 menit) dengan sub pokok bahasan yang dibahas adalah menjelaskan karakteristik administrasi perkantoran yang dilakukan oleh semua pihak dalam organisasi. Kegiatan pembelajaran siklus II ini dihadiri oleh 32 orang siswa, dengan perteuan pertama merupakan kegiatan pembelajaran, seddangan pertemuan ketiga merupakan pelaksanaan tes Siklus II. Hasil tes siklus I siswa dapat dilihat pada tabel di bawah ini.

Tabel 2 Hasil Tes Siklus II

\begin{tabular}{|l|l|l|l|l|}
\hline No & Nama & KK & Nilai & Keterangan \\
\hline
\end{tabular}


Sarinilam

\begin{tabular}{|c|l|c|c|c|}
\hline 1 & Ainnur Ramadhayanti & 75 & 88 & Tuntas \\
\hline 2 & Ajeng Wulan Dara & 75 & 93 & Tuntas \\
\hline 3 & Alvia Rahmati & 75 & 85 & Tuntas \\
\hline 4 & Chaula Salsabila & 75 & 95 & Tuntas \\
\hline 5 & Cut Anggun Triami & 75 & 72 & Tidak Tuntas \\
\hline 6 & Cut Keumala Nurul Fakhriyyah & 75 & 90 & Tuntas \\
\hline 7 & Cutti Hajar & 75 & 68 & Tidak Tuntas \\
\hline 8 & Dara Rizkina & 75 & 88 & Tuntas \\
\hline 9 & Della Fadhillah & 75 & 87 & Tuntas \\
\hline 10 & Desi Indrayana & 75 & 85 & Tuntas \\
\hline 11 & Daivina Salim & 75 & 95 & Tuntas \\
\hline 12 & Dian Prayatna & 75 & 82 & Tuntas \\
\hline 13 & Fia Herlika & 75 & 86 & Tuntas \\
\hline 14 & Husna Zaiti & 75 & 90 & Tuntas \\
\hline 15 & M. Iqbar Farisi & 75 & 88 & Tuntas \\
\hline 16 & M. Dodi Rahmatillah & 75 & 96 & Tuntas \\
\hline 17 & Marlisa Ulfa & 75 & 86 & Tuntas \\
\hline 18 & Miftahul Jannah & 75 & 90 & Tuntas \\
\hline 19 & Mirza Rizkia & 75 & 92 & Tuntas \\
\hline 20 & Mirza Ervirita & 75 & 87 & Tuntas \\
\hline 21 & Nianda Faradiba Sarbini & 75 & 90 & Tuntas \\
\hline 22 & Nova Sahara & 75 & 88 & Tuntas \\
\hline 23 & Putri Indah Seruni & 75 & 93 & Tuntas \\
\hline 24 & Putri Maryam Gunawan & 75 & 90 & Tuntas \\
\hline 25 & Raihan Aprilia & 75 & 95 & Tuntas \\
\hline 26 & Renita Shella Ramadhalena & 75 & 85 & Tuntas \\
\hline 27 & Sahlatul Fayza Nabila & 75 & 95 & Tuntas \\
\hline 28 & Sarah Samana & 75 & 86 & Tuntas \\
\hline 29 & Siska Maria & 75 & 90 & Tuntas \\
\hline 30 & Siti Hartini & 75 & 88 & Tuntas \\
\hline 31 & Syauqi Anshar & 75 & 87 & Tuntas \\
\hline 32 & Wulan Haliza & 75 & 70 & Tidak Tuntas \\
\hline Rata-rata Keseluruhan & & & 87,50 \\
\hline Persentase Tuntas & & & $92,50 \%$ \\
\hline Persentase Tidak Tuntas & & & $7,50 \%$ \\
\hline & & & & \\
\hline
\end{tabular}

Berdasarkan tabel di atas dapat diperhatikan bahwa dari 32 siswa yang mengikuti tes siklus II, siswa yang tuntas berjumlah 29 siswa sedangkan tidak tuntas berjumlah 3 siswa. Persentase siswa yang tuntas adalah sebesar 92,50\%dan yang tidak tuntas sebesar 7,50\%. Berdasarkan KKM yang terdapat di SMK Negeri 1 Banda Aceh, siswa dikatan tuntas secara individual jika memperoleh nilai minimal 75 dan siswa dikatakan tuntas secara klasikal apabila $\geq 85 \%$ siswa tuntas secara individual. Berdasarkan kriteria tersebut dapat disimpulkan bahwa hasil belajar siswa pada siklus II telah mencapai ketuntasan secara klasikal.

\section{c. Tahap Observasi Siklus II}

Pada tahap ini, guru yang manjadi observasi melaksanakan pengamatan secara langsung terhadap aktivitas guru dan aktivitas siswa selama pembelajaran berlangsung. 
Hasil pengamatan mereka diisikan pada lembar observasi yang telah peneliti siapkan. Berikut hasil observasi aktivitas guru pada siklus II.

Tabel 6. Observasi Aktivitas Guru Siklus II

\begin{tabular}{|c|c|c|}
\hline \multirow{2}{*}{ No } & Aspek yang Diamati & \multirow{2}{*}{$\begin{array}{c}\text { RPP } \\
\text { III }\end{array}$} \\
\hline & Kegiatan Pendahuluan & \\
\hline 1 & Kemampuan mengaitkan materi yang dipelajari dengan materi sebelumnya & 5 \\
\hline 2 & Guru memberikan contoh materi yang dipelajari dengan kehidupan sehari-hari siswa & 4 \\
\hline 3 & Guru menyampaikan tujuan pembelajaran. & 5 \\
\hline 4 & Guru menjelaskan kepada siswa tentang metode pembelajaran yang akan digunakan & 4 \\
\hline \multicolumn{3}{|c|}{ Kegiatan Inti } \\
\hline 5 & Kemampuan membentuk kelompok belajar siswa Guru memberikan nomor kepada siswa & 4 \\
\hline 6 & $\begin{array}{l}\text { Kemampuan mendorong para siswa agar bekerja sama dalam menyelesaikan LKS yang } \\
\text { diberikan }\end{array}$ & 5 \\
\hline 7 & $\begin{array}{l}\text { Kemampuan membimbing siswa untuk berdiskusi dan menemukan jawaban dari hasil diskusi } \\
\text { tersebut serta cara memecahkan soal, dengan memberikan bantuan terbatas }\end{array}$ & 5 \\
\hline 8 & Kemampuan mengoptimalkan interaksi siswa dalam belajar & 5 \\
\hline 9 & Kemampuan memimpin diskusi kelas/menguasai kelas & 5 \\
\hline 10 & $\begin{array}{l}\text { Kemampan mendorong siswa untuk menanggapi hasil presentasi temannya yang bernomor } \\
\text { sama }\end{array}$ & 5 \\
\hline 11 & Kemampuan mendorong siswa untuk mau bertanya & 4 \\
\hline 12 & Kemampuan mendorong siswa untuk mau mengeluarkan pendapat & 5 \\
\hline 13 & Kemampuan memotivasi siswa untuk menjawab pertanyaan & 4 \\
\hline 14 & $\begin{array}{l}\text { Menghargai berbagai pendapat siswa dan memberikan penghargaan terhadap hasil belajar } \\
\text { siswa sebagai motivasi belajar }\end{array}$ & 4 \\
\hline \multicolumn{3}{|c|}{ Penutup } \\
\hline 15 & $\begin{array}{l}\text { Kemampuan mengarahkan siswa untuk menemukan sendiri dan menarik kesimpulan tentang } \\
\text { karakteristik administrasi perkantoran }\end{array}$ & 5 \\
\hline 16 & Kemampuan menegaskan hal-hal penting intisari berkaitan dengan pembelajaran & 5 \\
\hline 17 & $\begin{array}{l}\text { Kemampuan menyampaikan judul sub materi berikutnya dan memberikan PR serta menutup } \\
\text { pelajaran }\end{array}$ & 4 \\
\hline \multicolumn{3}{|c|}{ Lain-lain } \\
\hline 18 & Antusias guru & 5 \\
\hline 19 & Antusias siswa & 5 \\
\hline \multicolumn{2}{|r|}{ Rata-rata } & 4,89 \\
\hline
\end{tabular}

Berdasarkan tabel di atas diketahui bahwasanya hampir seluruh indikator telah muncul, bahkan banyak indikator yang muncul dengan sempurna. Hal ini disebabakan peneliti melakukan perbaikan dalam proses pembelajaran yang dilakukan. Rata-rata hasil pengamatan observer terhadap aktivitas guru (peneliti) adalah 4,89. Sehingga mengalami peningkatan dibandingkan dengan siklus I. Sesuai dengan taraf keberhasilan tingkat kemampuan guru, maka dapat disimpulkan bahwa pembelajaran pada siklus II sangat baik. Berikut hasil observasi aktivitas siswa pada siklus II.

Tabel 7. Observasi Aktivitas Siswa Siklus II

\begin{tabular}{|c|c|c|c|}
\hline \multirow{2}{*}{ Aspek Pengamatan Aktivitas Siswa } & \multirow{2}{*}{ RPP I } & \multicolumn{2}{|c|}{ Persentase Kesesuaian (P) } \\
\cline { 3 - 4 } & & $\begin{array}{c}\text { Waktu } \\
\text { Ideal }\end{array}$ & Toleransi \\
\hline Mendengarkan/memperhatikan penjelasan guru/teman & 14,58 & $13 \%$ & $7 \% \leq \mathrm{P} \leq 18 \%$ \\
\hline
\end{tabular}


Sarinilam

\begin{tabular}{|l|c|c|c|}
\hline Membaca/memahami masalah di LKS & 10,41 & $10 \%$ & $5 \% \leq \mathrm{P} \leq 15 \%$ \\
\hline Menyelesaikan masalah atau menemukan solusi pemecahan masalah & 24,48 & $27 \%$ & $22 \% \leq \mathrm{P} \leq 32 \%$ \\
\hline $\begin{array}{l}\text { Membandingkan hasil temuan diskusi kelompok dengan hasil diskusi } \\
\text { kelompok lainnya }\end{array}$ & 32,63 & $30 \%$ & $25 \% \leq \mathrm{P} \leq 35 \%$ \\
\hline $\begin{array}{l}\text { Bertanya/menyampaikan pendapat/ide kepada guru atau teman } \\
\text { sekelompok }\end{array}$ & 10,41 & $10 \%$ & $5 \% \leq \mathrm{P} \leq 15 \%$ \\
\hline $\begin{array}{l}\text { Menarik kesimpulan suatu konsep yang ditemukan atau suatu prosedur } \\
\text { yang dikerjakan }\end{array}$ & 10,41 & $10 \%$ & $5 \% \leq \mathrm{P} \leq 15 \%$ \\
\hline $\begin{array}{l}\text { Perilaku yang tidak relevan dengan KBM (seperti: melamun, berjalan- } \\
\text { jalan di luar kelompok belajarny, membaca buku lain/mengerjakan } \\
\text { tugas mata pelajaran lain, bermain-main dengan teman atau } \\
\text { mengganggu teman dan lain-lain) }\end{array}$ & 2,08 & $0 \%$ & $0 \% \leq \mathrm{P} \leq 5 \%$ \\
\hline
\end{tabular}

Berdasarkan tabel di atas diketahui bahwa seluruh aspek aktivitas siswa pada siklus II sudah aktif. Masing-masing rata-ratanya adalah 14,58, 10,41, 24,48, 32,63, 10,41, 10,41 dan 2,08. Rata-rata tersebut berada pada toleransi waktu yang diberikan. Berdasarkan kriteria aktivitas siswa, bahwa aktivitas siswa dikatakan aktif jika setiap aspek aktivitas siswa yang diamati berada pada toleransi waktu yang diberikan. Berdasarkan kriteria tersebut dapat disimpulkan bahwa aktivitas siswa pada siklus II aktif (baik).

\section{d. Tahap Refleksi Siklus II}

Berdasarkan hasil observasi pada pembelajaran siklus II, diketahui bahwa peneliti telah melaksanakan pembelajaran dengan sempurna yaitu sesuai dengan Rencana Pelaksanaan Pembelajaran (RPP). Sehingga siswa bisa mengikuti langkah-langkah pembelajaran dengan baik dan penguasaan konsep siswa juga bagus. Nilai rata-rata siswa meningkat dan sudah tuntas secara klasikal.

\section{Angket Respon Siswa}

Setelah pelaksanaan pembelajaran siklus I dan siklus II selesai, guru membagikan angket kepada siswa untuk mengetahui bagaimana tanggapan siswa terhadap model pembelajaran kooperatif tipe NHT pada materi yang sudah diajarkan di SMK Negeri 1 Banda Aceh.

Dari angket respon siswa yang diisi oleh 32 siswa setelah mengikuti pembelajaran untuk materi administrasi perkantoran dengan model pembelajaran kooeratif NHT, maka diperoleh hasil dengan rincian seperti berikut.

Perasaan siswa terhadap komponen guru mengajar, dari aspek materi pelajaran 100 persen sisswa merasa senang, aspek LKS 100 persen siswa merasa senang, aspek tes hasil belajar 87,5 persen siswa merasa senang, suasana pembelajaran di kelas 93,8 persen siswa merasa senang, dan cara guru mengajar 100 persen siswa merasa senang. Mengenai kebaruan komponen pembelajaran, dari aspek materi pelajaran 100 persen siswa merasa baru, aspek LKS 75 persen merasa baru, aspek tes hasil belajar 100 persen siswa merasa baru, aspek suasana pembelajaran di kelas 100 persen siswa merasa baru, dan aspek cara guru mengajar 100 persen siswa merasa baru dalam hal cara guru mengajar. 
Serambi Akademica

Jurnal Pendidikan, Sains, dan Humaniora
Vol. 7, No. 4,

Oktober 2019
pISSN 2337-8085

eISSN 2657- 0998

\section{PENUTUP}

\section{Simpulan}

Berdasarkan hasil penelitian yang telah dilakukan tentang penerapan model pembelajaran kooperatif tipe NHT (Numbered Heads Together) pada materi karakteristik administrasi perkantoran di kelas X SMK Negeri 1 Banda Aceh, dapat disimpulkan bahwa: "penerapan model pembelajaran kooperatif tipe NHT (Numbered Heads Together) dapat meningkatkan hasil belajar siswa pada materi karakteristik administrasi perkantoran di kelas X SMK Negeri 1 Banda Aceh.

\section{DAFTAR PUSTAKA}

Huda Miftahul. 2013. Cooperative Learning. Pustaka Belajar. Yogjakarta. Ibrahim, Muslimin, dkk. 2006. Pembelajaran Kooperatif. Surabaya : Unesa Press.

Johar, Rahmah. 2006. Model Strategi Belajar Mengajar. Banda Aceh: FKIP Unsyiah. Kesumah, Wijaya. 2009. Mengenal Penelitian Tindakan Kelas. Jakarta: PT Indeks.

Nur, Mohamad. 2005. Pengajaran Berpusat Kepada Siswa dan Pendekatan Kontraktivis dalam Pengajaran. Surabaya: Pusat Studi MIPA Unesa.

Rustaman dkk. 2003. Stategi Belajar Mengajar. Bandung: UPI Bandung.

Susanto, Ahmad. 2013. Teori Belajar dan Pembelajaran di Sekolah Dasar. Jakarta: Kencana Prenadamedia Group.

Terry, George R dan Leslie W.Rue. 2014. Dasar-Dasar Manajemen, penerjemah G.A Ticoalu. Jakarta: PT Bumi Aksara.

Urge, Tim. 1997. Pembelajaran Kooperatif. Surabaya: Institut keguruan dan Ilmu Pendidikan Surabaya. 